\title{
POSZUKIWANIE PRAWDY OBIEKTYWNEJ A PEWNOŚĆ MORALNA SĘDZIEGO W KANONICZNYM PROCESIE MALŻEŃSKIM
}

Treść: Wstęp - 1. Proces o stwierdzenie nieważności małżeństwa jako służba prawdzie. - 2. Zasada prawdy obiektywnej. - 3. Prawda obiektywna a prawda „wyrokowa”. - 4. Pewność moralna jako przejaw dążenia do prawy obiektywnej. - 4.1. Pewność moralna w kanonicznym prawie procesowym. - 4.2. Prawdopodobieństwo - pewność moralna - pewność absolutna. - 5. Niektóre czynniki służące osiągnięciu pewności moralnej i wyświetleniu prawdy. - 5.1. Sędzia. - 5.2. Normy. dotyczące innych osób biorących udział w procesie. - Zakończenie.

\section{Wstęp}

„Przez sprawy o orzeczenie nieważności małżeństwa (...) albo sprawy o nieważność małżeństwa (...) należy rozumieć roztrząsanie przed właściwym sądem kościelnym sporu, czy dane małżeństwo zostało zawarte nieważnie i pozostaje nieważne z punktu widzenia prawa kanonicznego"'. Proces sądowy zmierza do ustalenia prawdy obiektywnej. W przemówieniu do Roty Rzymskiej z 4 II 1980 roku Jan Paweł II wskazał, że Kościół wypracował własną procedurę, która poszukując prawdy obiektywnej, gwarantuje stronom procesowym przedstawienie ich własnych racji oraz zabezpiecza nakaz Boży, który postanawia, by człowiek nie rozłączał tego, co złączył Bóg ${ }^{2}$. Natomiast w przemówieniu 28 I 1994 roku Ojciec św. zauważył, że prawda nie

1 T. Pawluk, Prawo kanoniczne wedtug Kodeksu Jana Pawła II, t. IV, Doczesne dobra Kościoła, Sankcje w Kościele, Procesy, Olsztyn 1990, s. 312.

2 Por. Joannes Paulus II, Allocutio ad Tribunalis Sacrae Romanae Rotae Decanum, Praelatos Auditores, Officiales et Advocatos, 4 II 1980, AAS 72(1980), s. 172178. 
zawsze jest łatwa, czasami jej afirmacja jest bardzo wymagająca. Nie może to jednak przeszkadzać w respektowaniu jej w komunikacji oraz w relacjach międzyludzkich. Zwłaszcza audytorom rotalnym, zauważył Jan Paweł II, znana jest próba zredukowania, w imię nieprawidłowej koncepcji współczucia oraz miłosierdzia, ciężkich wymogów płynących z zachowania prawa. Nie można zatem, podsumował Ojciec św., dopuścić do instrumentalizacji dowodów oraz norm procesowych, aby osiągnąć cel praktyczny ze szkodą dla prawdy i sprawiedliwości

Godność małżeństwa domaga się, aby Kościół, małżeństwo i opartą na nim rodzinę, ochraniał jak największą troską duszpasterską i bronił wszystkimi dostępnymi mu środkami ${ }^{4}$. Małżeństwo pozostaje więc pod szczególną opieką prawa. Oznacza to, że skoro zostanie ono zawarte zewnętrznie, należy uważać je za ważne, dopóki nie udowodni się, że na pewno jest nieważne. Dlatego w razie wątpliwości nie rozstrzygniętej, domniemanie prawne przemawia za ważnością małżeństwa (kan. $1060 \mathrm{KPK})^{5}$.

Ochrona rodziny i małżeństwa przez Kościół przejawia się także w wymaganiu osiągnięcia przez sędziego pewności moralnej do orzeczenia, że konkretne małżeństwo zostało zawarte nieważnie. Nie wystarczy prawdopodobieństwo nieważności, czy też przewaga dowodów i poszlak wskazujących na nieważność zawartego małżeństwa nad przesłankami przemawiającymi na korzyść węzła małżeńskiego. Pewność moralna, którą musi uzyskać sędzia wyrokujący za nieważnością zawartego małżeństwa nie musi jednak zawsze być zgodna z prawdą obiektywną. Może się przecież zdarzyć, że np. jedna ze stron procesu oraz świadkowie będą świadomie kłamać. Wówczas sędzia, wprowadzony w błąd, choć osiągnie w sumieniu moralną pewność, nie wyda wyroku zgodnego z prawdą obiektywną.

${ }^{3}$ Por. Joannes Paulus II, Allocutio ad Rotae Romanae Auditores, 28 I 1994, AAS 86(1994), s. 947-952.

${ }^{4}$ Por. Instrukcja, którą należy zachować w sądach diecezjalnych i międzydiecezjalnych w prowadzeniu spraw o nieważność matżeństwa, w: T. Rozkrut (red.), Komentarz do Instrukcji procesowej „Dignitas connubi”, Sandomierz 2007, s. 17.

5 Por. T. Pawluk, Prawo kanoniczne wedtug Kodeksu Jana Pawła II..., s. 313. 
Należy jednak zaznaczyć, że Prawodawca kościelny poprzez normę o wymaganiu pewności moralnej przy wydaniu jakiegokolwiek wyroku, zawartą w kan. $1608 \S 1 \mathrm{KPK}$, robi wszystko, aby została wyświetlona prawda obiektywna oraz ochrania małżeństwo i opartą na nim rodzinę.

\section{Proces o stwierdzenie nieważności małżeństwa jako służba prawdzie}

W przemówieniu do Roty Rzymskiej z 22 I 1996 roku, Jan Paweł II podkreślił, że sprawy nullitatis matrimonii należą do spraw o stanie osób oraz odnoszą się do dobra publicznego. Papież zaakcentował, iż wymiar procesów o nieważność małżeństwa jako dotyczących stanu osób, implikuje szereg przepisów mających na uwadze troskę o szybkie (w miarę możliwości) uchylenie wątpliwości zainteresowanych co do własnego statusu prawnego. Przepisy te stoją na straży praw strony dochodzącej prawdy o ważności lub nieważności zawartego związku małżeńskiego. Obowiązujące normy prawne, jak i uprawnienia stron procesowych nie powinny być naruszane. W kontekście procedury procesów małżeńskich, związanej z aspektem dobra publicznego, Jan Paweł II podkreślił, iż chodzi w niej o ustalenie rzeczywistości obiektywnej, jaką jest istnienie lub nieistnienie ważnego węzła małżeńskiego. Chociaż każdy z małżonków ma prawo wniesienia do kompetentnego trybunału skargi o nieważność zawartego małżeństwa, to nikomu nie przysługuje ani prawo do stwierdzenia ważności, ani prawo do stwierdzenia nieważności swego związku. Orzeczenie sądowe jest bowiem wyłącznie stwierdzeniem istniejącego stanu faktycznego. Prawda obiektywna, do ustalenia której zmierza postępowanie sądowe, jest dobrem, którym nie da się rozporządzać. Ojciec święty krytycznie ocenił wszelkie możliwe przejawy utrudniania trybunałowi przez strony procesowe dojścia do prawdy. Papież zwraca uwagę na równowagę zachodzącą pomiędzy prawami stron a potrzebą ustalenia prawdy obiektywnej. Prawda ta, związana z dobrem publicznym, nie może być pod żadnym pozorem zepchnięta na drugi plan $^{6}$. Rozpatrywanie spraw

\footnotetext{
${ }^{6}$ Por. W. GóRALSKI, Natura procesów o nieważność matżeństwa oraz zadania try-
} 
o nieważność małżeństwa stanowi służbę prawdzie, ponieważ broni autentyczności chrześcijańskiej koncepcji małżeństwa, także w obliczu kultur i mód, które usiłują ją zaciemnić. Służba prawdzie ma miejsce szczególnie wtedy, gdy odmawia się orzeczenia nieważności postulowanej przez współczesne założenia antropologiczne, nie dające się pogodzić z antropologią chrześcijańską ${ }^{7}$. Nie wolno naginać prawa - jako normy obiektywnej - do upodobań kogokolwiek. Naturę spraw o nieważność małżeństwa pozwala lepiej zrozumieć fakt niepowtarzalności człowieka ujmowanego w szerokim kontekście wielorakiej rzeczywistości, zwłaszcza kulturowej ${ }^{8}$.

Do wyświetlenia prawdy o człowieku trzeba sięgnąć do filozofii świadomego, wolnego i stanowiącego o sobie podmiotu. Z tym wnioskiem harmonizują normy kanonicznego prawa małżeńskiego. Do zaistnienia małżeństwa nie wystarczy spełnienie formalności i oświadczenie o woli zawarcia małżeństwa. Wymaga się dwóch aktów woli, które muszą być zgodne i dopiero ich zgodność konstytuuje małżeństwo. W miarę rozwoju nauk o człowieku, każde prawo „humanizuje się”, uwzględnia złożoność ludzkiego ,ja”, czyli podmiotu stanowiącego o osobie. Przykładem tego są normy kan. 1095 nn. 2 i 3 KPK, komentarze do nich oraz wykładnie ich aplikacji w orzecznictwie kościelnym. „Prawda o człowieku” każe go postrzegać w całej „,niepowtarzalnej rzeczywistości bytu i działania, świadomości i woli, sumienia i serca"9. Rozpoznana prawda o człowieku w określonym aspekcie jest podstawą orzekania sądów o małżeństwie. Orzeczenie o małżeństwie nie dotyczy instytucji jedynie prawnej ani tylko związku dwojga osób, lecz sakramentu. A to oznacza, iż orzeczenie sądu dotyczy rze-

bunału w ich prowadzeniu. Papież Jan Pawet II do Roty Rzymskiej 22 I 1996 r., Ius Matrimoniale 2(1997), s. 87-93.

7 Por. Z. Grocholewski, Sędzia kościelny wobec ekspertyz neuropsychiatrycznych i psychologicznych. Rozważania nad ostatnim przemówieniem Ojca Świętego w Rocie Rzymskiej, Prawo Kanoniczne 31(1988) nr 3-4, s. 96-97.

${ }^{8}$ Por. W. GóRALSKi, Natura procesów o nieważność matżeństwa oraz zadania trybunatu...., s. 87-93.

9 JAN PAWEL II, Encyklika Redemptor hominis, 14. 
czywistości nadprzyrodzonej: małżeństwo jest ważne lub nie wobec Boga i Kościoła ${ }^{10}$.

\section{Zasada prawdy obiektywnej}

Dla postępowania sądowego czymś istotnym jest zasada prawdy obiektywnej ${ }^{11}$. Zasada prawna jest to podstawowa norma prawna, podjęta przez naukę prawa na drodze intuicyjnego poznania słusznego porządku danej sprawy, to ogólne rozstrzygnięcie z zakresu porządku prawnego, podjęte czyimś autorytetem. Zasada w prawie procesowym jest to zasada prawna, odnosząca się do zakresu prawa procesowego. Od strony formalnej powinna ona być jednoznacznie wpisana w kodeks, ponieważ rozstrzyga wtedy o interpretacji prawa. Pozwala to na uniknięcie wątpliwości co do jej treści oraz co do jej obowiązywania. Jej konsekwencją jest interpretacja innych norm, a w sytuacji niezrozumienia jakiegoś przepisu, obowiązuje wykładnia według określonej zasady prawnej. W przypadku nieumieszczenia przez prawodawcę zasady prawnej w przepisach prawa, powstaje pytanie o myśl prawodawcy, pytanie o istnienie takiej zasady. Odpowiedź na te pytania wymaga prześledzenia wszystkich norm, porównania ich, szczegółowego zestawienia i wyszukiwania prawidłowości świadczących o istnieniu takiego wstępnego założenia. W sytuacji wątpliwości interpretacyjnej obowiązuje norma szczegółowa. W kościelnym prawie procesowym zasad procesowych w aspekcie formalno-prawnym nie ma. Nie ma zasad wpisanych do Kodeksu prawa kanonicznego. Jednakże w kościelnym prawie procesowym istnieje szereg zasad postawionych u progu zasad redakcyjnych, wynikających z natury Kościoła, które nakazują przyjęcie określonego modelu postępowania. Wśród nich jest właśnie zasada poszukiwania prawdy obiektywnej. Jest ona bowiem konsekwentnie obecna jako myśl prawodawcy w samej treści norm, a jej zastosowanie w interpretacji przepisów prawa, pozwala na właściwe zrozumienie i stosowanie samych norm w praktyce sądowej. Można

${ }^{10}$ Por. R. SoBAŃSKI, Iudex veritatem de matrimonio dicit, Ius Matrimoniale 4(1999), s. 185-186.

${ }^{11}$ Por. T. PAwLuK, Kanoniczny proces matżeński, Warszawa 1973, s. 105. 
zatem stwierdzić, że tę zasadę należy przyjąć jako jedną z podstawowych i obowiązujących w systemie kościelnego prawa procesowego ${ }^{12}$.

\section{Prawda obiektywna a prawda ,wyrokowa"}

Magisterium Kościoła podkreśla, że w procesie o nieważność małżeństwa chodzi o prawdę obiektywną ${ }^{13}$. Winna być ona we wszystkich procesach kościelnych „od początku aż do wyroku, podstawą, matką i prawem sprawiedliwości" ${ }^{14}$. Prawda obiektywna to odkrycie, rozpoznanie i zwerbalizowanie faktycznego stanu rzeczy. Jest istotą stwierdzania faktów prawnych. Jest to prawda pełna, w odróżnieniu od prawdy subiektywnej, będącej jedynie osobistym, podmiotowym przekonaniem osoby o pewnych faktach czy wydarzeniach, a przez to, siłą rzeczy, obiektywnie niepełną ${ }^{15}$. Normy procesu o nieważność małżeństwa bazują na przekonaniu, że można dojść do tej prawdy. Zakłada się więc zgodność prawdy obiektywnej i orzeczonej w wyroku, chociaż przepis kan. 1643 KPK, podający, że sprawy dotyczące stanu osób nigdy nie przechodzą w stan rzeczy osądzonej, wskazuje na to, iż nie wyklucza się niezgodności tych prawd. Norma ta ponadto potwierdza dążenie do „zwycięstwa” prawdy obiektywnej nad „wyrokową”. Można poza tym mówić o prawdzie moralnej, skoro do orzeczenia nieważności małżeństwa wymaga się tzw. pewności moralnej. Wobec wielości określeń prawdy wydaje się także zasadnym użycie terminu prawda prawna, to znaczy prawda ustalona zgodnie z przepisami pra-

${ }^{12}$ Por. A. DzIĘGA, Zasada poszukiwania prawdy obiektywnej w procesie kanonicznym, w: A. Dzięga, M. Greszata, P. Telusiewicz (red.), Kościelne Prawo Procesowe. Materiały i Studia, t. 4, Prawo Rodzinne, Lublin 2007, s. 172-188.

${ }^{13}$ Por. przemówienie PIUSA XII z 30 X 1941, AAS 33(1941), s. 421-426 i z 1 X 1942, AAS 34(1942), s. 338-342; Przemówienie JANA XXIII z 13 XII 1961, AAS 53(1961), s. 819; Przemówienie JANA PAWŁA II z 04 II 1980, AAS 72(1980), s. 174178, z 28 I 1982, AAS 74(1982), s. 449-454, z 25 I 1988, AAS 80(1988), s. 1178-1185; R. SOBAŃSKI, Iudex veritatem ..., s. 186.

${ }^{14}$ Joannes Paulus II, Allocutio ad Tribunalis Sacrae Romanae Rotae Decanum, Praelatos Auditores, Officiales et Advocatos, 4 II 1980, AAS 72(1980), s. 173.

${ }^{15}$ Por. A. DzIĘGA, Zasada poszukiwania prawdy..., s. 174. 
wa. Ta prawda prawna obiektywnie brzmi: to nie jest ważne, czyli nie jest obowiązujące, czyli nie jest prawdziwe małżeństwo ${ }^{16}$.

\section{Pewność moralna jako przejaw dążenia do prawy obiektywnej}

Gdy chodzi o całą dynamikę procesową, a zwłaszcza jej okres dowodowy i dyskusyjny, nadrzędną zasadą inspirującą przepisy księgi VII jest wymóg zawarty w kan. 1608 KPK, dotyczący osiągnięcia pewności moralnej, by sędzia mógł wydać wyrok na korzyść strony powodowej ${ }^{17}$. Samo pojęcie pewności moralnej zostało wypracowane przez Piusa XII ${ }^{18}$ i potwierdzone przez Jana Pawła II $^{19}$. Jak zaznacza E. McCarthy, jest ono ,punktem centralnym i syntezą całego (kanonicznego) prawa procesowego"20.

Pojęcie pewności moralnej jawi się jako bardzo ważny i właściwy klucz do lektury i interpretacji norm procesowych, które powinny być interpretowane w taki sposób, aby rzeczywiście służyły zagwarantowaniu poszukiwania prawdy obiektywnej. Osiągnięcie autentycznej pewności moralnej, czyli obiektywnie uzasadnionej wydaje się najwłaściwszą drogą do wyświetlenia prawdy, czyli osiągnięcia właściwego celu kanonicznego procesu o stwierdzenie nieważności małżeństwa ${ }^{21}$.

\subsection{Pewność moralna w kanonicznym prawie procesowym}

Chociaż w prawie kanonicznym ma zastosowanie zasada obowiązku wyrokowania ex actis et probatis ${ }^{22}$ (kan. 1608 §2 KPK), to jest tak-

\footnotetext{
${ }^{16}$ Por. R. Sobański, Iudex veritatem ..., s. 186-188.

${ }^{17}$ Por. Z. Grocholewski, Zasady inspirujace księge VII «de processibus» KPK, Ius Matrimoniale 4(1999), s. 157.

${ }^{18}$ PIus XII, Allocutio ad Prealatos Auditores Sacrae Romanae Rotae, 1 X 1942, AAS 34(1942), s. 338-343.

${ }^{19}$ Joannes Paulus II, Allocutio ad Tribunalis Sacrae Romanae Rotae..., s. 172-178.

${ }^{20} \mathrm{E}$. MCCARTHY, De certitudine morali quae in judicis animo ad sententiae pronuntiationem requintur, Romae 1948, s. 3; Z. Grocholewski, Zasady inspirujace księge VII..., s. 157.

${ }^{21}$ Por. Z. Grocholewski, Zasady inspirujące księgę VII..., s. 158.

${ }^{22}$ Ex actis - czyli z twierdzeń i zaprzeczeń, żądań i sprzeciwów przedstawionych wobec sądu i zawartych w aktach, a więc $z$ tego, co zostało dokonane podczas procesu (a nie z ,akt sądowych” w znaczeniu kan. 1522 KPK); ex probatis - czyli z dowodów
} 
że określone dalsze kryterium w pojęciu pewności moralnej, które precyzuje stan umysłu sędziego - oparty na acta et probata ocenionych w sumieniu - konieczny do wydania wyroku na korzyść powoda ${ }^{23}$.

Pewność moralna, jak już zasygnalizowano, winna pochodzić ex actis et probatis, zatem nie wchodzą w grę jako źródło pewności moralnej te informacje, które nie zostały przedstawione i przedyskutowane podczas procesu. Gdyby sędzia posiadał na podstawie prywatnych wiadomości jakieś elementy przeciwne temu, co wynika z akt, może dla uniknięcia niesprawiedliwego wyroku, uzupełnić z urzędu dowody zgodnie z kan. $1452 \mathrm{KPK}^{24}$.

Kanoniczno-procesowe pojęcie pewności moralnej dotyczy użycia naturalnej zdolności poznawczej przy ocenie wszystkiego, co zostało przedstawione i udowodnione w procesie. Nie wyklucza możliwości czegoś przeciwnego (w kategoriach filozoficznych pewność moralna kanoniczno-procesowa byłaby tylko opinią lub bardzo dużym prawdopodobieństwem ${ }^{25}$. Jan Paweł II w przemówieniu do Roty Rzymskiej z 1980 r., przywołując wcześniejsze przemówienie Piusa XII stwierdził, że ,żadnemu sędziemu, nie wolno wydać wyroku stwierdzającego nieważność małżeństwa, jeżeli nie uzyskał on przedtem pewności moralnej co do istnienia tejże nieważności. Nie wystarcza jedynie prawdopodobieństwo dla rozstrzygnięcia sprawy"26.

Pius XII wskazuje, że z reguły wystarcza minimalny stopień pewności moralnej, czyli wystarcza, że rzeczywiście posiada się (prawdziwą) pewność moralną obiektywną, tzn. że została wykluczona jakakolwiek

dostarczonych sądowi i zawartych w aktach. Por. R. Ludicke, Der kirchliche Ehenichtigkeitsprozeß nach dem Codex Iuris Canonici von 1983, Essen 1996, s. 248.

${ }^{23}$ Por. Z. Grocholewski, Pewność moralna jako klucz do lektury norm procesowych, Ius Matrimoniale 3(1998), s. 13.

${ }^{24}$ Por. I. Noval, De processibus, cz. I, De iudiciis, Romae 1920, s. 411; Z. GrochoLEWSKI, Pewność moralna..., s. 20-24.

${ }^{25}$ Por. W. Szafrański, Pewność moralna w kościelnym wyroku sadowym, Prawo Kanoniczne 1(1958), s. 283, 291-293, 304; J. Garcia FaILDE, Nuevo Derecho Procesal Canonico, Salamanca 1992, s. 206-207; Z. Grocholewski, Pewność moralna jako klucz..., s. 13-14.

${ }^{26}$ Por. Joannes Paulus II, Allocutio ad Tribunalis Sacrae Romanae Rotae..., s. 168. 
rozumna wątpliwość co do prawdy. Sędzia, raz się o tym upewniwszy, z reguły nie powinien szukać wyższego stopnia pewności ${ }^{27}$.

4.2. Prawdopodobieństwo - pewność moralna - pewność absolutna

Wspomniany Pius XII, w przemówieniu do Roty Rzymskiej z 1 X 1942 roku, aby lepiej ukazać sens określenia „pewność moralna”, najpierw przedstawia dwa inne pojęcia: pewności absolutnej i prawdopodobieństwa. Pewność absolutna to ta, w której jest całkowicie wykluczona jakakolwiek wątpliwość co do prawdy o fakcie i bezpodstawności czegoś przeciwnego. W odniesieniu do tej pewności papież stwierdza, że nie jest ona konieczna do wydania wyroku, ponieważ w wielu przypadkach człowiek nie może jej osiągnąć, domagać się jej oznaczałoby żądać rzeczy irracjonalnej od sędziego i stron oraz niosłoby ze sobą dla wymiaru sprawiedliwości obciążenie nie do zniesienia, a nawet w znacznej mierze paraliżowałoby przebieg procesu. Prawdopodobieństwo zaś (lub prawie-pewność), większe lub mniejsze, jest czymś przeciwstawnym pewności absolutnej i całkiem nie wyklucza rozumnej wątpliwości oraz dopuszcza uzasadnioną obawę pomyłki. Prawdopodobieństwo nie daje, według Piusa XII, wystarczającej podstawy do wyroku sądowego na temat obiektywnej prawdy co do faktu, a także, chociaż nie rzadko w języku potocznym jest ono nazywane (lub uważane) jako wiedza lub pewność, to jednak nie zasługuje na tę nazwę ${ }^{28}$.

Pomiędzy pewnością moralną a prawie-pewnością, czyli prawdopodobieństwem znajduje się pewność moralna. Ona, jak stwierdza papież, „od strony pozytywnej charakteryzuje się tym, że wyklucza jakąkolwiek uzasadnioną, czyli rozumną wątpliwość, i w ten sposób różni się istotnie od wspomnianej prawie-pewności; od strony zaś negatywnej, pozostawia absolutną możliwość czegoś przeciwnego, i w ten sposób odróżnia się od pewności absolutnej" ${ }^{29}$. Nie ma pewno-

${ }^{27}$ Por. PIUs XII, Allocutio..., 1 X 1942, s. 338-343.

${ }^{28}$ Por. Tamże.

${ }^{29}$ Tamże. Warto zauważyć, że wyrażenie: ,jakakolwiek uzasadniona, czyli rozumna wątpliwość" bywa zastępowane przez ,jakakolwiek roztropna wątpliwość" albo 
ści moralnej, kontynuuje papież, „gdy za czymś przeciwnym przemawiają motywy (...) przynajmniej w jakiś sposób godne uwagi"30.

Istotną cechę pewności moralnej stanowi obiektywizm, ponieważ „pewność ta ma być traktowana jako pewność obiektywna, czyli bazująca na motywach obiektywnych”31. Nie chodzi zaś o „pewność czysto subiektywną, bazującą na uczuciu bądź opinii czysto subiektywnej kogoś, czy też może na osobistej łatwowierności albo na braku rozwagi bądź doświadczenia"32.

Przedstawiona pewność moralna jest z jednej strony konieczna do wydania wyroku pozytywnego, a z drugiej strony wystarczająca nawet wtedy, gdyby w konkretnym przypadku było można osiągnąć bezpośrednio lub pośrednio pewność absolutną. Żaden trybunał kościelny nie ma prawa i władzy wymagać czegoś więcej, ponieważ tylko w taki sposób może mieć miejsce prawidłowy i uporządkowany wymiar sprawiedliwości, bez niepotrzebnych zwłok i nadmiernego obciążenia zarówno trybunału, jaki i stron ${ }^{33}$.

\section{Niektóre czynniki służące osiągnięciu pewności moralnej i wyświetleniu prawdy}

Wszyscy biorący udział w procesie kościelnym, a przede wszystkim sędzia, obrońca węzła, promotor sprawiedliwości i notariusz, powinni mieć na uwadze jeden cel: wyjaśnienia pełnej prawdy. Ten cel wyznacza strukturę procesu i funkcję wszystkich w nim uczestniczących. Wszyscy biorący udział w procesie powinni współpracować w osiąganiu pewności moralnej przez sędziego w tym znaczeniu, by każdy przyczyniał się do współpracy wypełniając sumiennie swoje specyficzne zadanie w dialektyce procesowej. Osiągnięcie pewności

\footnotetext{
,jakakolwiek roztropna wątpliwość czyli oparta na pozytywnych przesłankach”. Por. Tamże.

${ }^{30}$ Tamże.

${ }^{31}$ Tamże.

${ }^{32}$ Tamże.

${ }^{33}$ Por. Pius XII, Allocutio..., 1 X 1942, s. 338-343; Z. GrocholewsKi, Pewność moralna..., s. 26.
} 
moralnej przez sędziego jest największym gwarantem wyświetlenia prawdy.

\subsection{Sędzia}

Sędzia kościelny to najwyższy gwarant prawdy obiektywnej, ponieważ jego decyzje są decyzjami podejmowanymi w Imię Boga $^{34}$. Z urzędu sędziego wynika władza sędziowska, a decyzja sędziego, podejmowana $\mathrm{w}$ jego sumieniu jest wiążąca dla stron procesu, dlatego winna być ona maksymalnie odpowiedzialna za sprawy i życie każdego wiernego ${ }^{35}$. Prawodawca w kan. 1608 §1 KPK stanowi: „do wydania jakiegokolwiek wyroku wymaga się u sędziego wewnętrznej moralnej pewności co do sprawy, która ma być rozstrzygnięta wyrokiem"36. Aby móc skutecznie podjąć się drogi zmierzającej do osiągnięcia pewności obiektywnej, sędzia musi mieć odpowiednie cechy osobowościowe i właściwe przygotowanie. Nie dają gwarancji osiągnięcia pewności moralnej, charakteryzującej się obiektywizmem, zarówno osoby odznaczające się osądami ekstrawaganckimi, niezrównoważone, powierzchowne, zbyt skrupulatne lub przeciwnie, pozbawione większych skrupułów, jak i te, które nie posiadają odpowiedniego przygotowania kanonistycznego do pełnienia urzędu sędziego. Można również dodać do tego tych sędziów, którzy nie wierzą w wartości, które winny być bronione podczas procesu, co ma szczególne znaczenie w sprawach o nieważność małżeństwa, bowiem tylko ci, którzy wierzą $\mathrm{w}$ te wartości, będą je na serio brać pod uwagę ${ }^{37}$. Należy też

\footnotetext{
${ }^{34}$ Por. Kan. 1420 KPK.

${ }^{35}$ Por. R. SzTychmiler, Sąownictwo kościelne w stużbie praw człowieka, Olsztyn 2000, s. 58.

${ }^{36}$ Należy zauważyć, że sformułowanie to nie jest całkiem precyzyjne. Nie jest bowiem prawdą, że sędzia musi posiadać pewność moralną do wydania ,jakiegokolwiek wyroku". Musi ją posiadać jedynie do wydania wyroku, który przyznaje rację powodowi, czy uznaje prawo przezeń dochodzone (i to tylko na tyle na ile ją uznaje); nie natomiast do wydania wyroku negatywnego odnośnie do żądań powoda. Por. Z. Grocholewski, Pewność moralna jako klucz ..., s. 9-10.

${ }^{37}$ Por. Pius XII, Allocutio..., 1 X 1942; Z. Grocholewski, Pewność moralna jako $k l u c z . . .$, s. 32-33.
} 
wspomnieć o pewnej ,pokorze” sędziego, ponieważ doświadczenie i rutyna - same w sobie cenne - powodują nieraz, że sędzia ,z góry wie”, czy sprawa ma szansę, co może rodzić pokusę prowadzenia sprawy tak, by potwierdzić własny, uprzedzający sprawę sąd. Tylko sędzia, który zachowuje krytycyzm wobec własnego doświadczenia i wobec swojej wiedzy, może być prawdziwie obiektywny ${ }^{38}$. Dzieje się tak dlatego, ponieważ stosowanie prawa nie polega jedynie na operacji logicznej, czyli przeprowadzeniu rozumowania według sylogizmu, lecz następuje w wyniku rozumowania oceniającego, za pomocą którego sędzia musi zbudować przesłanki. Do tego z kolei trzeba wchodzące w grę przepisy oraz fakty nie tylko ustalić, ale również zinterpretować. Do prawdy sędzia dochodzi więc przez ocenę. Dlatego prawodawca ustala kryteria tej oceny, przy czym kryteria te nie podlegają interpretacji, a ponadto one również są wynikiem oceny (dokonanej przez prawodawcę). Nie można wykluczyć u sędziego konfliktu sumienia polegającego na rozdźwięku między jego wewnętrznym przekonaniem, czyli jego oceną dowodów, a oceną według kryteriów prawa. Sędzia bowiem ocenia dowody w sumieniu, ale subiektywnie, co oznacza, że odejście od kryteriów ustawowych wymaga uzasadnienia na podstawie materiałów zawartych w aktach sprawy ${ }^{39}$.

Chociaż w sądowej procedurze kościelnej obowiązuje zasada swobodnej oceny dowodów, to nie oznacza ona subiektywizmu czy irracjonalizmu, lecz wymaga od sędziego wysiłku intelektualnego kierowanego obiektywnymi przesłankami. Pius XII we wspomnianej wcześniej alokucji stwierdza, że sędzia powinien zdecydować zgodnie z własną wiedzą i sumieniem, czy zebrane dowody i przeprowadzone dochodzenie są wystarczające, lub nie, do uzyskania koniecznej pewności moralnej co do prawdy ${ }^{40}$.

${ }^{38}$ Por. A. Kaufmann, Problemgeschichte der Rechtsphilosophie, w: A. Kaufmann, W. Hassemer (red.), Einfi,ihrung in Rechtsphilosophie und Rechtstheorie der Gegenwart, Heidenberg 1985, s. 115; R. SoBAŃSKI, Iudex veritatem ..., s. 188.

39 Por. R. Sobański, Iudex veritatem ..., s. 189.

${ }^{40}$ Por. PIUs XII, Allocutio..., 1 X 1942, s. 338-343. 
5.2. Normy dotyczące innych osób biorących udział w procesie

Kolejną osobą biorącą udział w procesie i stojącą na straży prawdy obiektywnej i pomagającej sędziemu w osiągnięciu pewności moralnej, jest obrońca węzła małżeńskiego. Jego zadaniem jest wskazywanie na to wszystko, co świadczy o tym, że małżeństwo zostało zawarte ważnie. Ukazuje on sędziemu te elementy, które są przeciwko rozłączeniu małżonków. Dostarcza argumentów, które jego zdaniem, są przekonujące. Jeśli do elementów zgłoszonych przez strony procesu, można dodać coś, co ukaże ich prawdę subiektywną jako element prawdy obiektywnej, to obrońca ma obowiązek to uczynić. Zatem zadanie obrońcy węzła małżeńskiego jest w swej istocie posługą na rzecz prawdy obiektywnej, do której sędzia powinien dotrzeć poprzez uzyskanie pewności moralnej ${ }^{41}$. Nie do pogodzenia ze starannym i wiernym wypełnieniem obowiązków obrońcy węzła małżeńskiego jest to, gdyby zadowalał się on tylko pobieżnym przeglądaniem akt i powierzchownymi uwagami. Jego praca powinna być bowiem pomocą dla sędziów oraz uzupełnieniem ich działania. Byłoby także sprzeczne z prawdą, gdyby obrońca węzła chciał sporządzić i przygotować sztuczną obronę za wszelką cenę, bez troski o to, czy jego zastrzeżenia mają poważną podstawę czy też nie. Podobnie, byłoby wypaczeniem jego specyficznego zadania we wspólnym dochodzeniu do prawdy i w konsekwencji do pewności moralnej, jak również byłoby wywierającym przeciwny skutek zakłóceniem prawidłowego poszukiwania prawdy, gdyby obrońca węzła chciał uzurpować sobie zadania adwokata dostarczając argumentów za nieważnością małżeństwa lub sędziego wypowiadając się co do meritum sprawy ${ }^{42}$.

Pius XII w przemówieniu do Roty Rzymskiej z 2 X 1944 roku $^{43}$ szczególnie podkreślił jedność celu, czyli wydobycie prawdy, mówiąc o funkcjach obrońcy węzła i adwokata. Jeden i drugi działa bowiem pro rei veritate. Odmienne są ich punkty wyjściowe i cele najbliższe,

\footnotetext{
${ }^{41}$ Por. A. DzIĘGA, Zasada poszukiwania prawdy..., s. 175.

${ }^{42}$ Por. Pius XII, Allocutio..., 2 X 1944, s. 281-290.

${ }^{43}$ Por. Pius XII, Allocutio ad Praelatos Auditores Sacrae Romanae Rotae, 2 X 1944, AAS 36(1944), s. 281-190.
} 
ale wspólny jest cel końcowy procesu, czyli prawda o konkretnym małżeństwie. Papież zdecydowanie przeciwstawił się poglądowi, jakoby ocena prawdy należała wyłącznie do sędziego, zaś zobowiązanie adwokata do prawdy polegałoby na paraliżowaniu jego aktywności. Obrońca węzła i adwokat stają na odmiennych pozycjach wyjściowych, jeden pro vinculo, drugi pro nullitate, ale obydwaj zawsze służą prawdzie. Sędzia, obrońca węzła i adwokat odgrywają przypisane im role, ale są to role wzajemnie skoordynowane i pozostające w służbie prawdy i dobra dusz ${ }^{44}$. Chociaż punktem wyjściowym adwokata jest ,prawda strony”, to i on pozostaje w służbie obiektywnej prawdy materialnej ${ }^{45}$.

Również promotor sprawiedliwości, występujący w procesach w zależności od potrzeby jako oskarżyciel, powód lub uczestnik procesu, ma na celu wyjaśnienie prawdy obiektywnej. Jeżeli występuje jako oskarżyciel, jest inicjatorem postępowania i gromadzi pewne prawdy subiektywne, które musi w ramach swego urzędu ocenić, czyli dojść do prawdy maksymalnie zbliżonej do obiektywnej ${ }^{46}$.

Podobnie inni biorący udział w procesie: notariusz, strony, świadkowie i biegli winni współdziałać w dotarciu do prawdy obiektywnej.

Poszukiwanie prawdy domaga się zachowania norm kanonicznych, które wyłączają niektóre osoby od obowiązku udzielenia odpowiedzi w charakterze świadków ze względu na ,tajemnicę zawodową”. Od takiej powinności prawo zwalnia duchownych, w odniesieniu do informacji uzyskanych przez nich z racji sprawowania świętej posługi, urzędników państwowych, lekarzy, położne, adwokatów, notariuszy i innych zobowiązanych do zachowania tajemnicy urzędowej, także $\mathrm{z}$ racji udzielania porady $\mathrm{w}$ zakresie spraw objętych tą tajemnicą. Ponadto, prawo zwalnia od tego obowiązku także te osoby, które w wyni-

${ }^{44}$ Por. PIus XII, Allocutio..., 1 X 1942, s. 338-342; Joannes Paulus II, Allocutio ad Rotae Romanae Auditores, 25 I 1988, AAS 80(1988), s. 1178-1185; R. SoBAŃSKI, Udziat adwokata $w$ procesie o nieważność matżeństwa, Ius Matrimoniale 2(1997), s. 131-132.

${ }^{45}$ Por. R. SobAŃsKi, Udział adwokata..., s. 132.

${ }^{46}$ Por. Tamże, s. 176. 
ku swego zeznania obawiają się dla siebie lub współmałżonka niebezpiecznych przykrości lub innego poważnego zła ${ }^{47}$.

Wyświetlenie prawdy obiektywnej wymaga także przedstawienia stosownych dokumentów jako środków dowodowych. Jan Paweł II w przemówieniu do Roty Rzymskiej w dniu 26 I 1989 roku zaakcentował, iż nikt nie ma obowiązku przedkładania dokumentów, nawet wspólnych, które nie mogą być ujawnione bez niebezpieczeństwa szkody dla siebie, współmałżonka, bliskich krewnych lub powinowatych, albo bez niebezpieczeństwa naruszenia tajemnicy, którą należy zachować. Sędzia, zgodnie z brzmieniem kan. 1546 § 2 KPK, może nakazać, by dokument został przedłożony tylko wtedy, gdy jest możliwe przepisanie niewielkiej części dokumentu i przedstawienie go w odpisie $\mathrm{z}$ wykluczeniem niebezpieczeństwa szkody stron i naruszenia tajemnicy ${ }^{48}$.

\section{Zakończenie}

Prawda orzekana przez sędziego dotyczy konkretnego małżeństwa ocenianego w świetle obiektywnej prawdy o małżeństwie, którą Kościół poznaje, przekazuje, stosuje i kształtuje. Pewność moralna daje wystarczającą (i konieczną) podstawę na temat prawdy obiektywnej. Gdyby sędzia nie był w stanie osiągnąć pewności moralnej, musi orzec, że nie udowodniono nieważności małżeństwa, chociaż prawda obiektywna może być inna, lecz tylko brak dowodów na jej potwierdzenie. I odwrotnie, może się zdarzyć, że sędzia osiągnie pewność moralną opartą na fałszywych dowodach czy przesłankach.

Należy jeszcze raz podkreślić, że prawodawca kościelny czyni wszystko, aby umożliwić wyświetlenie prawdy obiektywnej na podstawie pewności moralnej, którą osiąga sędzia. Pewność moralna i prawda obiektywna powinny być zatem ze sobą zgodne. Istnieje wszakże możliwość, że nie będą one oznaczały tej samej rzeczywistości. Po-

\footnotetext{
${ }^{47}$ Por. Kan. 1548 §2 KPK; H. StawniaK, Prawo do obrony w procesie kanonicznym (Refleksje na kanwie przemówienia Jana Pawła II do Roty Rzymskiej $w$ dniu 26.01.1989 roku), Prawo Kanoniczne 33(1990) nr 1-2, s. 149.

${ }^{48}$ Por. H. Stawniak, Prawo do obrony $w$ procesie..., s. 149.
} 
twierdza to kan. 1643 KPK, podający, że sprawy dotyczące stanu osób nigdy nie przechodzą w stan rzeczy osądzonej.

\section{The Search for the Objective Truth and Moral Certainty of the Judge In the Canonical Process of Marriage}

The legal proceeding which also contains the canonical process concerning the statement of an annulment of marriage aims to establish the objective truth. The Judge should have the moral certainty which is necessary and sufficient at the same time to establish the truth.

This article aims to show the connection between these notions, the difference between moral certainty, probability and absolute certainty. This article also discusses those elements in Canon Law which help one to gain moral certainty, as well as revealing the objective truth.

This article is intended as a help in a scholarly investigation of the canonical processes concerning marriage. 